\title{
Variasi Waktu Pembacaan Setelah Stop Solution Terhadap Nilai Absorbansi Anti Hbs Metode Elisa
}

\author{
Fithrah Hudaini $^{1}$, Budi Santosa ${ }^{2}$, Aprilia Indra Kartika ${ }^{2}$ \\ ${ }^{1}$ Mahasiswa DIV Analis Kesehatan Unversitas Muhammadiyah Semarang, Indonesia \\ ${ }^{2}$ Dosen Magister Sains Laboratorium Klinik/Medik Universitas Muhammadiyah Semarang, Indonesia
}

\begin{tabular}{l}
\hline Article Info \\
\hline Article history: \\
Received, Mei $31^{\text {th }}, 2020$ \\
Revised, Sep $15^{\text {th }}, 2020$ \\
Accepted, Sep $17^{\text {th }}, 2020$ \\
\hline
\end{tabular}

\section{Keywords:}

Hepatitis B

Anti HBs

ELISA

Stop Soluton

\begin{abstract}
Enzyme-Linked Immunosorbent Assay (ELISA) is a biochemical technique used in the field of immunology to presence detection of antibodies or antigens in a sample. After providing a stop solution, it is necessary to know the right time for the absorbance reading. The purpose of this study was to determine the anti HBs titer with absorbance reading time variation (immediate, 30 minutes and 60 minutes). This research is an experimental study. The study population was D4 Health Analyst University Student Muhammadiyah Semarang Class 2018 after hepatitis B vaccination as many as 20 . To know the difference in variation during the reading, Kruskal-Wallis test was conducted. The results showed the average absorbance at an immediate reading, 30, and 60 minutes complete in complete 1,931, 1,489, 1,276. Kruskal-Wallis statistical analysis obtained a $p$ value of 0.00 . The conclusion is obtained between the variation of absorbance reading time on the ELISA method
\end{abstract}

Copyright (C) Jurnal Analis Medika Biosains (JAMBS) All rights reserved

Kata Kunci : Bepatitis B.Anti HBs, ELISA, Stop Solution

\section{Pendahuluan}

Hepatitis adalah peradangan atau infeksi pada sel-sel hati. Penyakit Hepatitis B disebabkan oleh virus Hepatitis B yang bersifat akut atau kronik dan termasuk penyakit hati yang paling berbahaya.(Aini \& Susiloningsih, 2013) Anti-HBs merupakan antibodi spesifik untuk HBsAg yang timbul setelah terinfeksi oleh virus Hepatitis B atau setelah vaksinasi Hepatitis B yang bersifat protektif.(Kasih \& Hapsari, 2017) Keberhasilan suatu vaksinasi dapat diketahui berdasarkan pengukuran titer antibodi yang terbentuk melalui pemeriksaan laboratorium. (Astuti \& Kusumawati, 2014) 
ELISA digunakan dalam bidang imunologi untuk mendeteksi kehadiran antibodi dalam suatu sampel. Prinsip dari pemeriksaan ELISA adalah untuk mendeteksi anti-hbs menggunakan metode antigen sandwich ELISA, strip polistiren microwell yang telah dilapisi dengan HBsAg rekombinan. Sampel serum atau plasma pasien ditambahkan ke dua domain variabel dari antibodi. Selama inkubasi, immunocomplex spesifik yang terbentuk ditangkap pada fase padat. Setelah pencucian untuk menghilangkan sampel dan konjugat HRP yang tidak terikat, larutan kromogen yang mengandung tetramethylbenzidine (TBM) dan urea peroksida ditambahkan ke dalam sumur. Pada kompleks "sanwich" antigen-antibodi-antigen (HRP), reaksi kromogen tidak berwarna dengan asam sulfat. Jumlah intensitas warna dapat diukur dan sebanding dengan jumlah antibodi yang ditangkap di sumur dan masing-masing sampel.(Suou, 2020)

Pembacaan pada ELISA ada beberapa hal yang perlu diperhatikan antara lain panjang gelombang, waktu pembacaan absorbansi dan ketelitian serta ketepatan dalam pemeriksaan itu sendiri. Pembacaan absobansi harus dilakukan segera setelah penambahan Stop Solution. Pada prosedur Kit WANTAI antiHBs ELISA (Quantitative) dijelaskan pembacaan absorbansi dalam pemeriksaan ELISA ini dibaca dalam waktu 10 menit dengan menggunakan panjang gelombang 450 nm.(Acids \& Absorption, 2020)

Inkubasi merupakan salah satu faktor yang dapat mempengaruhi hasil absorbansi pada pemeriksaaan sampel menggunakan ELISA. Pembacaan absobansi harus dilakukan segera setelah penambahan Stop Solution:(Idexx, 2012) Penelitian sebelumnya yang telah dilakukan oleh Andini (2016),(Andini, 2016) dapat dilihat hasil penelitiannya secara deskriptif yang memiliki perbedaan variasi waktu pembacaan absorbansi yang dilakukan 1 menit, 15 menit dan 30 menit, tetapi pada uji statistik tidak ada perbedaan yang bermakna. Hal ini mendorong peneliti untuk melakukan uji variasi waktu pembacaan setelah penambahan stop solution (segera, 30 menit dan 60 menit) terhadap nilai absorbansi dengan metode ELISA sehingga dapat mengetahui ke akuratan dari metode tersebut.

\section{Metode Penelitian}

Jenis penelitian iniadalah eksperimen berdasarkan intervensi variasi waktu pembacaan setelah penambahan stop solution. Populasi diambil dari mahasiswa D4 Analis Kesehatan pasca vaksinasi Hepatitis B. Jumlah Sampel sebanyak 20 diambil secara consecutive sampling. Pemeriksaan Anti HBs dilakukan pada sampel (serum) dan WANTAI anti-HBs ELISA (Quantitative)(Wantai, n.d.) di Laboratorium Imunologi Universitas Muhammadiyah Semarang pada bulan oktober 2019. Pembacaan absorbansi pada alat Elisa Reader setelah penambahan stop solution pada waktu segera, 30 menit, dan 60 menit. Perbedaan absorbansi berdasarkan variasi suhu dilakukan dengan uji Kruskal Wallis karena data berdistribusi tidak normal menggunakan SPSS versi.. Sampel penelitian ini diambil dari bank sampel sumsum tulang yang dimiliki oleh laboratorium Patologi Klinik Universitas Muhammadiyah Semarang dan telah mendapatkan ijin dengan nomor 012/L.PK/02/19. 


\section{Hasil Penelitian}

Telah dilakukan penelitian tentang variasi waktu pembacaan setelah stop solution terhadap nilai absorbansi anti hbs metode elisa. Penelitian ini menggunakan desain cross sectional atau potong lintang dan dilakukan di Laboratorium Biologi Molekuler Universitas Muhammadiyah Semarang.

Pada penelitian ini sampel yang digunakan adalah sampel darah mahasiswa D4 Jalur Khusus Analis Kesehatan FIKKES Universitas Muhammadiyah Semarang Angkatan 2018 post Vaksinasi Hepatitis B sebanyak 20 orang. Sampel yang digunakan adalah sampel darah vena yang telah dilakukan centrifugasi, serum yang telah dipisahkan kedalam cup sampel disimpan di dalam Freezer bersuhu $-2^{\circ} \mathrm{c}$, kemudian dilakukan pemeriksaan dengan metode ELISA

\section{Rerata Nilai Absorbansi}

Tabel 1. Rerata hasil nilai absorbansi berdasarkan variasi waktu pembacaan setelah penambahan stop solition dengan metote ELISA

\begin{tabular}{cccc}
\hline $\begin{array}{c}\text { Waktu } \\
\text { Pembacaa } \\
\mathrm{n} \\
\begin{array}{c}\text { Absorban } \\
\text { si }\end{array}\end{array}$ & $\begin{array}{c}\text { Rata- } \\
\text { rata } \\
(\mathrm{mIU} / \mathrm{ml} \\
)\end{array}$ & $\begin{array}{c}\text { Tertinggi } \\
(\mathrm{mIU} / \mathrm{ml})\end{array}$ & $\begin{array}{c}\text { Terendah } \\
(\mathrm{mIU} / \mathrm{ml})\end{array}$ \\
\hline Segera & 1.931 & 2.650 & 0.015 \\
\hline 30 Menit & 1.489 & 2.036 & 0.012 \\
\hline 60 Menit & 1.276 & 1.735 & 0.008 \\
\hline
\end{tabular}

Tabel menunjukan nilai absorbansi dengan variasi waktu pembacaan absorbansi pada metode ELISA tertinggi yaitu pada pembacaan stop solution segera didapatkan hasil konsentrasi anti-HBs sebesar 2.650 $\mathrm{mIU} / \mathrm{ml}$ dan terendah yaitu pada pembacaan 60 menit didapatkan hasil konsentrasi anti-HBs sebesar 0.008 $\mathrm{mIU} / \mathrm{ml}$.

\section{Uji Normalitas}

Tabel 2. Hasil Uji Normalitas Shapiro-Wilk

\begin{tabular}{|c|c|c|c|}
\hline & $\begin{array}{r}\text { Waktu } \\
\text { pembacaan }\end{array}$ & $\begin{array}{c}\text { Shapiro } \\
\text { Wilk }\end{array}$ & \\
\hline & & $\begin{array}{l}\text { Statisti } \\
\mathrm{c}\end{array}$ & Sig \\
\hline \multirow{3}{*}{$\begin{array}{l}\text { Nilai } \\
\text { (Absorbansi) }\end{array}$} & Segera & $.677 \quad 20$ & .000 \\
\hline & 30 Menit & .680 & .000 \\
\hline & 60 Menit & .667 & .000 \\
\hline
\end{tabular}


Tabel hasil uji normalitas pembacaan absorbansi segera, 30 menit dan 60 menit didapatkan hasil (sig $<0.00$ ) data terdistribusi tidak normal

\section{Uji Kruskal-Wallis}

Tabel 3. Hasil Uji Kruskal-Wallis

\begin{tabular}{lr}
\hline & \multicolumn{2}{c}{ Nilai } \\
& (Absorbansi) \\
\hline Chi-Square & 20.359 \\
\hline Df & 2 \\
\hline Asymp. Sig. & .000 \\
\hline
\end{tabular}

Tabel hasil analisis statistik menggunakan uji Kruskal-Wallis didapatkan nilai probabilitas atau signifikansi pada pembacaan absorbansi segera, 30 menit dan 60 menit yaitu (sig 0,00) sehingga diketahui hasil bahwa ada perbedaan antara variasi waktu pembacaan absorbansi pada metode ELISA

Pembacaan pada ELISA reader menunjukan tiap variasi waktu memiliki absorbansi yang berbeda. Kadar absorbansi menunjukkan adanya perbedaan dalam variasi waktu pembacaan. Hasil analisis statistik juga membuktikan bahwa nilai probabiltas atau signifikansi yaitu ( $\operatorname{sig} 0,00: \mathrm{p}>0,05$ ) yang membuktikan bahwa ada perbedaan antara variasi waktu pembacaan absorbansi pada metode ELISA. Hasil penelitian yang didapat menunjukkan adanya variasi waktu pembacaan absorbansi memberikan perubahan terhadap hasil antara perbedaan waktu segera, 30 dan 60 menit yang menandakan bahwa waktu pembacaan absorbansi setelah penambahan stop solution dapat mempengaruhi hasil apabila dilakukan penundaan.

Penelitian sebelumnya yang telah dilakukan oleh Andini (2016),(Andini, 2016) dapat dilihat hasil penelitiannya secara deskriptif yang memiliki perbedaan variasi waktu pembacaan absorbansi yang dilakukan 1 menit, 15 menit dan 30 menit, tetapi pada uji statistik tidak ada perbedaan yang bermakna.

Reagen stop solution harus memenuhi dua persyaratan utama: 1) untuk menghentikan reaksi dengan secara efektif menghambat aktivitas enzimatik HRP, 2) untuk menstabilkan produk teroksidasi dari substrat kromogenik atau fluorogenik. Asam yang kuat digunakan sebagai stop reagen untuk menghambat aktivitas enzim peroksidase. Hal ini terutama terjadi ketika 3,3'-5,5' Tetramethylbenzidine (TMB) berfungsi sebagai substrat warna dan enzim peroksidase dihambat dengan menyesuaikan $\mathrm{pH}$ ke nilai $\mathrm{pH} 2$ atau bahkan lebih rendah. Pada kasus TMB, stop solution, asam sulfiric, tidak hanya menghambat pengembangan warna tetapi juga mengubah produk oksidasi biru TMB menjadi turunan kuning yang memiliki absorptivitas molar yang lebih tinggi secara signifikan yaitu 450mn (Research Gate.2017). (Evers, 2020) Prosedur kit yang tertera setelah penambahan stop solution sebaiknya pembacaan hasil absorbansi dilakukan kurang dari 10 menit agar mendapatkan hasil yang baik dan akurat.

\section{Kesimpulan}

Terdapat perbedaan yang signifikan terhadap nilai absorbansi anti-HBs dengan variasi waktu pembacaan segera, 30 menit, dan 60 menit setelah penambahan stop solution metode ELISA 


\section{Daftar Pustaka}

Acids, S., \& Absorption, M. (2020). ELISA stop solution, What concentration of acid? 1-7.

Aini, R., \& Susiloningsih, J. (2013). Faktor Resiko yang Berhubungan dengan Kejadian Hepatitis B pada Pondok Pesantren Putri Ibnul Qoyyim Yogyakarta. Sains Medika, 5(1), 30-33.

Andini, S. T. (2016). Titer Anti-HBS Dengan Variasi Waktu Pembacaan Absorbansi pada ELISA Reader. Universitas Muhammadiyah Semarang, 1-46.

Astuti, H. P., \& Kusumawati, E. (2014). Kajian Efektifitas Pemberian Vaksinasi Hepatitis B Terhadap Pembentukan Antibodi Anti HBs. KesMaDaSka, 29-34.

Evers, R. (2020). ELISA Immunoassay Enzyme Immunoassay Bioassays. 1-5.

Idexx. (2012). ELISA Technical Guide. April, 30.

Kasih, T., \& Hapsari, R. (2017). Profil Anti-Hbs Sebagai Penanda Kekebalan Terhadap Infeksi Virus Hepatitis B Pada Mahasiswa Kedokteran. Diponegoro Medical Journal (Jurnal Kedokteran Diponegoro), 6(2), 1279-1289.

Suou, I. (2020). Why sulfuric acid can act as the stop solution in ELISA? 1-7.

Wantai. (n.d.). the Healthanti-HBs Quantitative (WB-2896).Developing Scientifically Focusing on. 